\title{
Allenes and Acetylenes. XXIV. Synthesis of $\alpha$-Allenic Amines by Organocuprate Reactions of Acetylenic Aminoethers
}

\author{
CHRISTER SAHLBERG and ALF CLAESSON
}

Department of Organic Pharmaceutical Chemistry, Biomedical Center, University of Uppsala, Box 574, S-751 23 Uppsala, Sweden

Tertiary $\alpha$-allenic amines $1 a-d$ are formed in good yields in reactions of acetylenic aminoethers with an organocuprate reagent, derived from butylmagnesium bromide and $5-20 \%$ of $\mathrm{CuI}$, in tetrahydrofuran (THF) or THF - diethyl ether 3:1. The overall reduction reaction proceeds through an organometallic intermediate which is protonated on work-up. Primary and tertiary $\alpha$-allenic amines $7 a-d$ are formed in moderate to good yields in 1,3-substitution reactions $\left(\mathbf{S}_{\mathrm{N}} 2^{\prime}\right)$ of acetylenic aminoethers with organocuprates in diethyl ether. The organocuprate reagents are derived from methylmagnesium or benzylmagnesium halide and $10 \%$ of $\mathrm{CuI}$ or $\mathrm{CuBr}$. The choice of solvent in these alleneforming reactions is of crucial importance in steering the reactions in one of the two directions.

Mitochondrial monoamine oxidase (MAO) is an enzyme which plays an important role in the oxidative deamination of transmitter amines. ${ }^{1}$ MAO is inhibited by several types of compounds, ${ }^{2}$ some of which can be used clinically, mainly in the treatment of depression. ${ }^{3}$ Acetylenic (propargylic) amines are among the most studied inhibitors. They are mechanism-based irreversible inhibitors of MAO and their mode of action involves enzyme-mediated formation of an unknown reactive intermediate which reacts in the active site to form covalent bonds with the flavin unit of MAO. The allenic amine $1 a$, a known inhibitor of $\mathrm{MAO},{ }^{4}$ was shown by Krantz and Lipkowitz to give an unidentified adduct with

$$
\begin{aligned}
& \begin{array}{c}
\stackrel{\mathrm{CH}_{3}}{\mathrm{Ph}}-\mathrm{CH}_{2}-\mathrm{N}-\mathrm{R} \\
\text {. }
\end{array} \\
& \text { la } \mathrm{R}=\mathrm{CH}_{2}-\mathrm{CH}=\mathrm{C}=\mathrm{CH}_{2} \\
& 2 \mathrm{R}=\mathrm{CH}_{2}-\mathrm{C}=\mathrm{C}-\mathrm{CH}_{3}
\end{aligned}
$$

MAO. ${ }^{5}$ The unstable adduct is not identical with that obtained from the isomeric acetylene 2 which gives a flavocyanine. ${ }^{6}$ The structure of the adduct is currently being elucidated through collaborative efforts by the research groups of Professor Krantz, Dr. Salach and our group. ${ }^{7}$ For these studies a method for preparing isotope-labeled $\alpha$-allenic amines, particularly amine $1 a$, was needed. Since the work, on our part, involves studies of structureactivity relationships of allenic amines as MAO inhibitors, it was highly desirable to use synthetic methods which permit structure variation. The synthetic methods ${ }^{8}$ known at the time of commencement of this work were not judged suitable. Since then some synthetic methods for allenic amines have been reported. ${ }^{9}$ The above considerations have led us to develop new synthetic methods for $\alpha$ allenic amines. A method for primary $\alpha$-allenic amines has been published. ${ }^{10}$ The present paper

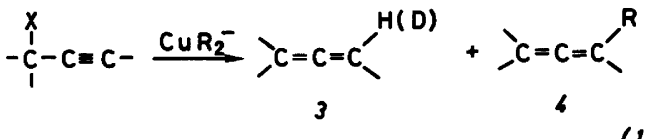

describes in detail ${ }^{11}$ a synthetic method for tertiary $\alpha$-allenic amines which is based on the known ability of organocuprates to give "reduced" allenes 3 besides alkylated allenes 4 in reactions with propargylic acetates ${ }^{12}$ and other propargylic derivatives $^{13}$ (eqn. 1). The method has been applied in synthesis of allenic prostaglandins. ${ }^{14}$ Speculations have been made about the mechanism of this reduction reaction ${ }^{12 b},{ }^{13 a}$ and studies on the same type of reduction of allylic ethers have been reported. $^{15}$ 
<smiles>COC(C)C#CCN(C)CCC(N)(Br)Br</smiles>

13<smiles>COC(C)C#CCN</smiles>

A synthesis of allenic primary and tertiary amines by, formally, $\mathrm{S}_{\mathrm{N}} 2^{\prime}$ reactions of the same aminoethers with organocuprates is also reported in the present paper (Scheme 2).

\section{RESULTS}

The starting aminoethers $(5 a-f)$ were prepared in high yields from a secondary amine, paraformaldehyde and a propargylic methyl ether by the Mannich reaction. Compound $5 g$ was synthesized as outlined in eqn. 2 .

The aminoethers $5 a-e$ were allowed to react with a butylcuprate, derived from butylmagnesium bromide and $\mathrm{CuI}$ in tetrahydrofuran (THF) or THF diethyl ether (ether) $3: 1$. The allenic amines $(1 a-d)$ were obtained in good yields (Table 1, Scheme 1).
In entry 1 , allene $1 a$ was accompanied by an equal amount of the isomeric amine 2. Compound $1 a$ was isolated by preparative GLC. In entries 2, 3 and 4 , allenes $1 b-d$ were formed in good isolated yields, and only small amounts, $<5 \%$, of isomeric acetylenes were detected. The existence of the organometallic intermediate 6 was confirmed by hydrolyzing the reaction mixture in entry 8 with $\mathrm{D}_{2} \mathrm{O}$. The allene $1 b-d_{1}$ thus obtained had a deuterium incorporation of $>99 \%$, as determined by mass spectrometry and NMR. Several unsuccessful attempts were made to achieve reduction of the aminoether $5 e$ under the above conditions. Preliminary attempts (not shown in Table 1) to prepare primary and secondary $\alpha$-allenic amines by the method described in Scheme 1 led to mixtures of products and further attempts were not made.

Scheme 1.

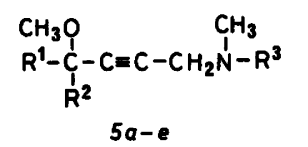

$5 a-e$

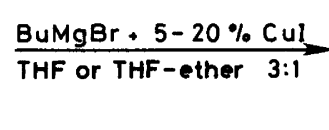

$\underset{\text { THF or THF-ether 3:1 }}{\mathrm{BuMgBr}+5-20 \% \mathrm{Cul}}$<smiles>[R]C([R])C#CC(CNC)NC</smiles>

6<smiles>[R]NCC(C=C([R])[R])CNC</smiles>

$1 a-d$

Table 1. Reactions of 5 with $\mathrm{BuMgBr}+\mathrm{CuI}$ in $\mathrm{THF}-$ ether 3:1 (Scheme 1).

\begin{tabular}{lllllllll}
\hline Entry & $\begin{array}{l}\text { Methyl } \\
\text { ether } 5\end{array}$ & $\mathrm{R}^{1}$ & $\mathrm{R}^{2}$ & $\mathrm{R}^{3}$ & $\mathrm{CuI}(\%)^{a}$ & $\begin{array}{l}\text { Reaction } \\
\text { time } \\
(\mathbf{h})\end{array}$ & $\begin{array}{l}\text { Allenic } \\
\text { amine } \\
1\end{array}$ & $\begin{array}{l}\text { Isolated } \\
\text { yield } \\
(\%)\end{array}$ \\
\hline 1 & $5 a$ & $\mathrm{H}$ & $\mathrm{H}$ & $\mathrm{CH}_{2} \mathrm{Ph}$ & 20 & 3 & $1 a$ & $40^{b}$ \\
2 & $5 b$ & $\mathrm{CH}_{3}$ & $\mathrm{H}$ & $\mathrm{CH}_{2} \mathrm{Ph}$ & 20 & 3.5 & $1 b$ & 62 \\
3 & $5 c$ & $\mathrm{CH}_{3}$ & $\mathrm{CH}_{3}$ & $\mathrm{CH}_{2} \mathrm{Ph}$ & 20 & 4 & $1 c$ & 70 \\
$4^{c}$ & $5 d$ & $\mathrm{C}_{3} \mathrm{H}_{7}$ & $\mathrm{H}$ & $\mathrm{CH}_{3}$ & 10 & 2 & $1 d$ & 63 \\
5 & $5 e$ & $\left.\mathrm{C}^{c} \mathrm{CH}_{3}\right)_{3}$ & $\mathrm{H}$ & $\mathrm{CH}_{2} \mathrm{Ph}$ & 20 & & & 0 \\
6 & $5 a$ & $\mathrm{H}$ & $\mathrm{H}$ & $\mathrm{CH}_{2} \mathrm{Ph}$ & 10 & 2.5 & $1 a$ & $40^{b}$ \\
7 & $5 b$ & $\mathrm{CH}_{3}$ & $\mathrm{H}$ & $\mathrm{CH}_{2} \mathrm{Ph}$ & 5 & 3 & $1 b$ & $80^{b}$ \\
$8^{d}$ & $5 b$ & $\mathrm{CH}_{3}$ & $\mathrm{H}$ & $\mathrm{CH}_{2} \mathrm{Ph}$ & 20 & 2.5 & $1 b-d_{1}$ & $80^{b}$ \\
\hline
\end{tabular}

${ }^{a}$ Relative to BuMgBr. ${ }^{b}$ GLC-yield. ${ }^{c}$ Solvent: THF. ${ }^{d}$ Hydrolyzed with $\mathrm{D}_{2} \mathrm{O}$. 


$$
\begin{gathered}
\stackrel{C H_{3}}{I}-C_{2}-C D=C=\mathrm{CHCH}_{3} \\
I b-d_{1}
\end{gathered}
$$

If, instead of THF, ether is used as the solvent in similar organocuprate reactions, alkylated allenes are obtained. Thus, amines $7 a, b, f$ and $g$ were obtained in variable yields through reactions of the aminoethers $5 a, b, f$ and $g$ with a methyl or benzyl cuprate in ether (Table 2, Scheme 2). This reaction

$$
\begin{gathered}
\mathrm{CH}_{2} \mathrm{OCH}_{3} \\
\mathrm{Ph}-\mathrm{CH}_{2}-\mathrm{C}=\mathrm{CH}-\mathrm{CH}_{2} \mathrm{~N}\left(\mathrm{CH}_{3}\right)_{2}
\end{gathered}
$$

was found to be $100 \%$ regioselective, since in no case were acetylenic amines obtained. From the reaction of compound $5 f$ with benzylmagnesium chloride and $10 \%$ of $\mathrm{CuBr}$, the addition product 8 was isolated in a yield of about $20 \%$.

\section{DISCUSSION}

The results in Table 1 indicate that the reduction depicted in Scheme 1 is quite general and that it can be used as a synthetic method for many tertiary $\alpha$-allenic amines. However, certain bulky substituents $\left(R^{1}\right.$ or $\left.R^{2}\right)$ on the propargylic carbon in the aminoether 5 , as in $5 e$, obviously present hindrance when $5 e$ is attacked by the cuprate (entry 5 , Table 1). No other reasons but steric ones are available to explain this unexpected result. Similar failures to reduce a propargylic aminoether containing an amide function in the $R^{1}$ substituent $\left(R^{2}=H\right)$ have been reported. ${ }^{16}$

In the two types of reactions described above the acetylenic aminoethers are either reduced or undergo substitution, mainly depending on the solvent. Thus, THF gives reduction and ether gives substitution. Butylmagnesium bromide plus $10 \%$ of a $\mathrm{Cu}(\mathrm{I})$ halide, however, gives about $35 \%$ of reduction products on reaction with the aminoether $5 b$ when the solvent is ether. ${ }^{17}$ Neither we ${ }^{18}$ nor other authors, ${ }^{19}$ however, have noted any reduction under similar conditions when the acetylenic ether does not contain an amino group. The ability of the solvent to steer the reaction in either direction can be explained by considering the reaction mechanism(s) which, however, is not yet fully elucidated. It is generally assumed that cuprate reagents, like other $d^{10}$ complexes, often react with electrophiles by oxidative addition, i.e. a copper(III) species is a transient intermediate which then gives the products by reductive elimination. ${ }^{20}$ An alternative explanation pertaining to substrates having $\pi$-electrons is loose complex formation followed by addition (unsaturated ketones) or addition-elimination (e.g. the present propargylic compounds). ${ }^{21}$

As mentioned above, reduction of propargylic compounds has been encountered earlier. Other authors ${ }^{12 b},{ }^{13 a}$ have attempted to explain the formation of these products by postulating a stable trialkylcopper(III) species which is hydrolyzed during work-up. Since no such alkyl complex has ever been isolated, ${ }^{22}$ the postulation is indeed remarkable and, if true, has far-reaching consequences. A more likely explanation is a reduction - oxidation process

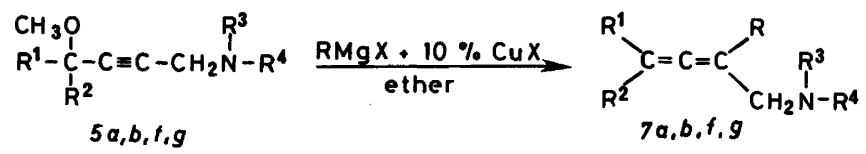

\begin{tabular}{|c|c|c|c|c|c|c|c|c|c|c|}
\hline Entry & $\begin{array}{l}\text { Methyl } \\
\text { ether } 5\end{array}$ & $\mathrm{R}^{1}$ & $\mathbf{R}^{2}$ & $\mathrm{R}^{3}$ & $\mathbf{R}^{4}$ & $\mathrm{RX}$ & $\mathrm{CuX}$ & $\begin{array}{l}\text { Reaction } \\
\text { time } \\
\text { (h) }\end{array}$ & $\begin{array}{l}\text { Allenic } \\
\text { amine } \\
7\end{array}$ & $\begin{array}{l}\text { Isolated } \\
\text { yield } \\
(\%)\end{array}$ \\
\hline $\begin{array}{l}1 \\
2 \\
3 \\
4\end{array}$ & $\begin{array}{c}5 a \\
5 b \\
5 f \\
5 g\end{array}$ & $\begin{array}{l}\mathrm{H} \\
\mathbf{H} \\
\mathrm{H} \\
\mathrm{H}\end{array}$ & $\begin{array}{l}\mathrm{H} \\
\mathrm{CH}_{3} \\
\mathrm{H} \\
\mathrm{CH}_{3}\end{array}$ & $\begin{array}{l}\mathrm{CH}_{2} \mathrm{Ph} \\
\mathrm{CH}_{2} \mathrm{Ph} \\
\mathrm{CH}_{3} \\
\mathrm{H}\end{array}$ & $\begin{array}{l}\mathrm{CH}_{3} \\
\mathrm{CH}_{3} \\
\mathrm{CH}_{3} \\
\mathrm{H}\end{array}$ & $\begin{array}{l}\mathrm{CH}_{3} \mathrm{I} \\
\mathrm{CH}_{3} \mathrm{I} \\
\mathrm{PhCH}_{2} \mathrm{Cl} \\
\mathrm{CH}_{3} \mathrm{I}\end{array}$ & $\begin{array}{l}\mathrm{CuI} \\
\mathrm{CuI} \\
\mathrm{CuBr} \\
\mathrm{CuBr}\end{array}$ & $\begin{array}{r}3 \\
21 \\
15 \\
20\end{array}$ & $\begin{array}{l}7 a \\
7 b \\
7 f \\
7 g\end{array}$ & $\begin{array}{l}60 \\
70 \\
20 \\
42\end{array}$ \\
\hline
\end{tabular}

Scheme 2.

Table 2. Reactions of 5 with $\mathrm{RMgX}+10 \% \mathrm{CuX}$ in ether (Scheme 2). 
in which the cuprate is oxidized to alkanes by the acetylenes, which are thus reduced. In some unknown way, THF obviously promotes this reduction reaction more than ether does. We have also found that propargylic methyl ethers are reduced to a somewhat greater extent than are propargylic acetates. ${ }^{17}$ This is in accordance with the more pronounced differences found in the corresponding reactions of certain allylic ethers and acetates. ${ }^{15}$ The results in both cases might be explained by relative slowness of a reductive elimination of a copper-(III) intermediate caused, at least in part, by a copper-bound methoxide ligand. It is conceivable that such an intermediate complex might simply be reduced by another copper(I) species or rearrange internally before elimination. ${ }^{15}$ In both cases an ambident propynyl-propadienyl anion $9, c f .6$, would be the result. The possible role of the solvent could be to alter the structure and/or dynamics of the copper(III) intermediate (e.g. $\sigma$

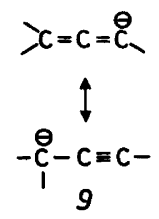

versus $\pi$-complex). These speculative mechanistic considerations are developed more fully elsewhere for the allylic case. ${ }^{15}$

The protonation of the ambident anion 9 was surprisingly regioselective when $\mathbf{R}^{1}$ and/or $\mathbf{R}^{2}$ equalled the alkyl. Only $\leq 5 \%$ acetylenic amines were formed, which were readily removed. However, when $\mathbf{R}^{1}=\mathbf{R}^{2}=\mathbf{H}$ the allenic and acetylenic amines $1 a$ and 2 , respectively, were formed in equal amounts. The same regioselectivity was not displayed by a corresponding anion which lacked the amino function. ${ }^{17}$ Here, the acetylene was the main product. The role of the amino nitrogen is not readily apparent, but some kind of chelating effect in the anion 6 might be invoked.

Formation of tertiary $\alpha$-allenic amines by reactions of Grignard reagents with acetylenic aminoethers of the present type is known. ${ }^{23}$ However, the yields increase when catalytic amounts of $\mathrm{CuBr}$ are used, as we have done (Table 2, Scheme 2). Similar improvements of the yields have been observed in the synthesis of allenic hydrocarbons from acetylenic ethers. ${ }^{19}$ The alkylation reaction in Scheme 2 was highly regioselective when $R=M e$, $\mathrm{CH}_{2} \mathrm{Ph}$. Moreover, no reduced products were detected. However, reactions of $5 b$ with ethyl- or butylcuprate also gave "reduced" allenes besides alkylated ones. ${ }^{17}$

The mechanism of the reaction in Scheme 2 might be either an oxidative addition-reductive elimination process ${ }^{20}$ or a cis addition of alkylcopper over the acetylenic bond followed by 1,2elimination of copper methoxide. ${ }^{24}$ Similar additions of organocopper reagents to acetylenes are known. ${ }^{25}$ The last-mentioned mechanism might be valid in some cases since the reaction of $5 f$ with a benzylcuprate (entry 3, Table 2) produced equal amounts of the addition product 8 and the allene $7 f$.

The alkylation reaction in Scheme 2, in contrast to the reduction reaction, is applicable to the synthesis of primary amines (cf. entry 4 , Table 2). The yields are not, however, as high as for the synthesis of tertiary amines.

\section{EXPERIMENTAL}

General. IR spectra were recorded on a PerkinElmer Infracord 157G spectrophotometer, and mass spectra (at $70 \mathrm{eV}$ ) on an LKB 9000 instrument. These spectra were routinely recorded and are in full accordance with the proposed structures. Melting points were determined in open capillary tubes and are uncorrected. Elemental analyses were carried out by the Microanalytical Laboratory, Royal Agricultural College, Uppsala. GLC analyses were performed on a Varian 1700 chromatograph equipped with a $2.7 \mathrm{~m}$ glass column packed with $8 \%$ Carbowax $20 \mathrm{M}+2 \% \mathrm{KOH}$ on Chromosorb W (60-80 mesh) or, for preparative use, a $3.0 \mathrm{~m}$ steel column packed with $20 \%$ Carbowax $20 \mathrm{M}$ on Chromosorb W (60-80 mesh). THF was distilled from $\mathrm{LiAlH}_{4}$. All reactions with organocopper reagents were carried out under nitrogen.

\section{Preparation of starting materials}

3-Methoxy-1-hexyne (10). This was prepared by standard methods, using 3-hexyn-3-ol, $\mathrm{NaH}$ and $\mathrm{CH}_{3} \mathrm{I}$ in ether-dimethyl formamide (DMF) 1:1. Yield: $41 \%$ b.p. $48^{\circ} \mathrm{C} / 32 \mathrm{mmHg}$. NMR $\left(\mathrm{CDCl}_{3}\right)$ $0.95(\mathrm{t}, 3 \mathrm{H}), 1.4-1.9(\mathrm{~m}, 4 \mathrm{H}), 2.46\left(\mathrm{~d},{ }^{4} \mathrm{~J} \sim 2 \mathrm{~Hz}, 1 \mathrm{H}\right)$, $3.44(\mathrm{~s}, 3 \mathrm{H}), 3.85-4.1(\mathrm{~m}, 1 \mathrm{H})$.

4,4-Dimethyl-3-methoxy-1-pentyne (11). This was prepared by standard methods, using 4,4-dimethyl1-pentyn-3-ol, prepared according to a general procedure, ${ }^{26} \mathrm{NaH}$ and $\mathrm{CH}_{3} \mathrm{I}$ in ether-DMF 1:1. Yield: $50 \%$, b.p. $52^{\circ} \mathrm{C} / 75 \mathrm{mmHg}$. NMR $\left(\mathrm{CDCl}_{3}\right)$ $0.96(\mathrm{~s}, 9 \mathrm{H}), 2.34\left(\mathrm{~d},{ }^{4} \mathrm{~J} \sim 2 \mathrm{~Hz}, 1 \mathrm{H}\right), 3.37(\mathrm{~s}, 3 \mathrm{H}), 3.48$ (d, $\left.{ }^{4} \sim 2 \mathrm{~Hz}, 1 \mathrm{H}\right)$. 
1-Bromo-4-methoxy-2-pentyne (12). To a stirred solution of cyanogen bromide $(32.0 \mathrm{~g}, 0.3 \mathrm{~mol})$ in ether $(400 \mathrm{ml})$ at $25^{\circ} \mathrm{C}$ was added $N, N$-dibutyl-4methoxy-2-pentynylamine (13) $(68.0 \mathrm{~g}, 0.3 \mathrm{~mol})$ over a 30-min period. The mixture was stirred for an additional $12 \mathrm{~h}$ and then washed with $1 \mathrm{M} \mathrm{HCl}$ $(3 \times 50 \mathrm{ml})$ and water $(2 \times 50 \mathrm{ml})$. The organic phase was dried over $\mathrm{MgSO}_{4}$, concentrated in vacuo and distilled at reduced pressure to give $39.2 \mathrm{~g}(74 \%)$ of 12 , b.p. $70-75^{\circ} \mathrm{C} / 10 \mathrm{mmHg}$. IR (film) $2200 \mathrm{~cm}^{-1}$. NMR $\left(\mathrm{CDCl}_{3}\right) 1.35\left(\mathrm{~d},{ }^{3} \mathrm{~J} \sim 7 \mathrm{~Hz}, 2 \mathrm{H}\right), 3.37(\mathrm{~s}, 3 \mathrm{H})$, $3.94\left(\mathrm{~d},{ }^{5} \sim 2 \mathrm{~Hz}, 2 \mathrm{H}\right), 3.9-4.3(\mathrm{~m}, 1 \mathrm{H})$.

4-Methoxy-2-pentynylamine $(5 \mathrm{~g}) .8 .5 \mathrm{~g}(0.048$ mol) of 12 was added to about $50 \mathrm{ml}$ of liquid $\mathrm{NH}_{3}$ in a tube which was sealed for $3 \mathrm{~h}$. The excess of $\mathrm{NH}_{3}$ was then allowed to evaporate and ether $(200 \mathrm{ml})$ was added. The ether phase was washed with $\mathrm{H}_{2} \mathrm{O}(10 \mathrm{ml})$ and dried over $\mathrm{Na}_{2} \mathrm{CO}_{3}$. The ether was distilled off and the residue was distilled in vacuo to give $5.4 \mathrm{~g}(60 \%)$ of $5 \mathrm{~g}$, b.p. $62-63{ }^{\circ} \mathrm{C} / 12 \mathrm{mmHg}$. NMR $\left(\mathrm{CDCl}_{3}\right) 1.32(\mathrm{~s}, 2 \mathrm{H}), 1.38\left(\mathrm{~d},{ }^{3} \mathrm{~J} \sim 7 \mathrm{~Hz}, 3 \mathrm{H}\right)$, $3.33(\mathrm{~s}, 3 \mathrm{H}), 3.42$ (d. $\left.{ }^{5} \sim 7 \mathrm{~Hz}, 2 \mathrm{H}\right), 3.8-4.2(\mathrm{~m}$, $1 \mathrm{H})$.

General procedure for preparation of acetylenic aminoethers (Mannich reactions). A mixture of an appropriate secondary amine (1.1 equiv.), paraformaldehyde (1.2 equiv.), an appropriate acetylenic methyl ether (1.0 equiv.) and $\mathrm{CuCl}(0.01$ equiv.) in dioxane was refluxed for $2 \mathrm{~h}$. The solvent was removed in vacuo and the reaction mixture was poured into ice-water. The mixture was acidified and extracted twice with ether. The aqueous layer was made basic and extracted three times with chloroform. Drying over $\mathrm{K}_{2} \mathrm{CO}_{3}$, evaporation of the solvent and distillation in vacuo gave the appropriate aminoether.

$\mathrm{N}$-(4-Methoxy-2-butynyl)-N-methylbenzylamine (5a). The standard procedure was followed, using 3-methoxy-1-propyne ${ }^{26}$ and $N$-methylbenzylamine. Yield: $89 \%$ b.p. $90-92^{\circ} \mathrm{C} / 0.2 \mathrm{mmHg}$. NMR $\left(\mathrm{CDCl}_{3}\right) 2.33(\mathrm{~s}, 3 \mathrm{H}), 3.35(\mathrm{t}, 2 \mathrm{H}), 3.40(\mathrm{~s}, 3 \mathrm{H})$, $3.58(\mathrm{~s}, 2 \mathrm{H}), 4.15(\mathrm{t}, 3 \mathrm{H}), 7.35(\mathrm{~s}, 5 \mathrm{H})$.

$\mathrm{N}-(4-M e t h o x y-2$-pentynyl)-N-methylbenzylamine (5b). The standard procedure using 3-methoxy-1butyne ${ }^{27}$ and $N$-methylbenzylamine gave $5 b$ in a yield of $71 \%$, b.p. $106-108^{\circ} \mathrm{C} / 0.6 \mathrm{mmHg}$. NMR $\left(\mathrm{CDCl}_{3}\right) 1.43\left(\mathrm{~d},{ }^{3} \mathrm{~J} \sim 7 \mathrm{~Hz}, 3 \mathrm{H}\right), 2.32(\mathrm{~s}, 3 \mathrm{H}), 3.33$ $(\mathrm{d}, 2 \mathrm{H}), 3.41(\mathrm{~s}, 3 \mathrm{H}), 3.55(\mathrm{~s}, 2 \mathrm{H}), 3.95-4.3(\mathrm{~m}, 1 \mathrm{H})$, $7.35(\mathrm{~s}, 5 \mathrm{H})$.

$\mathrm{N}$-(4-Methoxy-4-methyl-2-pentynyl)-N-methylbenzylamine $(5 \mathrm{c})$. The standard procedure was followed, using 3-methoxy-3-methyl-1-butyne ${ }^{28}$ and $N$-methylbenzylamine. Yield: $76 \%$, b.p. $87^{\circ} \mathrm{C} / 0.1$ mmHg. NMR $\left(\mathrm{CDCl}_{3}\right) 1.50(\mathrm{~s}, 6 \mathrm{H}), 2.32(\mathrm{~s}, 3 \mathrm{H}) 3.34$ $(\mathrm{s}, 2 \mathrm{H}), 3.41(\mathrm{~s}, 3 \mathrm{H}), 3.56(\mathrm{~s}, 2 \mathrm{H}), 7.35(\mathrm{~s}, 5 \mathrm{H})$.

$\mathrm{N}, \mathrm{N}$-Dimethyl-4-methoxy-2-heptynylamine (5d). The mixture was heated in a sealed tube; otherwise the standard procedure was followed, using 10 , dimethylamine hydrochloride and one equivalent of $\mathrm{K}_{2} \mathrm{CO}_{3}$. Yield: $53 \%$, b.p. $84-86^{\circ} \mathrm{C} / 12 \mathrm{mmHg}$. NMR $\left(\mathrm{CDCl}_{3}\right) 0.95(\mathrm{t}, 3 \mathrm{H}), 1.35-1.8(\mathrm{~m}, 4 \mathrm{H})$, $2.30(\mathrm{~s}, 6 \mathrm{H}), 3.29$ (d, $2 \mathrm{H}), 3.39(\mathrm{~s}, 3 \mathrm{H}), 3.8-4.2(\mathrm{~m}$, $1 \mathrm{H})$.

$\mathrm{N}-(5,5-D i m e t h y l-4-m e t h o x y-2-h e x y n y l)-\mathrm{N}-m e t h$ ylbenzylamine ( $5 \mathrm{e})$. The standard procedure using 11 and $N$-methylbenzylamine gave $5 e$ in a yield of $70 \%$. B.p. $98-99^{\circ} \mathrm{C} / 0.06 \mathrm{mmHg}$. NMR $\left(\mathrm{CDCl}_{3}\right)$ $1.00(\mathrm{~s}, 9 \mathrm{H}), 2.35(\mathrm{~s}, 3 \mathrm{H}), 3.3-3.5(\mathrm{~m}, 5 \mathrm{H}), 3.5-3.7$ (m, 3H), 7.35 (s, 5H).

N,N-Dibutyl-4-methoxy-2-pentylamine (13). The standard procedure was followed, using 3-methoxy1-butyne ${ }^{27}$ and dibutylamine. Yield: $82 \%$, b.p. $84-87^{\circ} \mathrm{C} / 0.4 \mathrm{mmHg}$. NMR $\left(\mathrm{CDCl}_{3}\right) 0.90(\mathrm{t}, 6 \mathrm{H})$, $1.15-1.75(\mathrm{~m}, 11 \mathrm{H}), 2.45(\mathrm{t}, 4 \mathrm{H}), 3.35-3.50(\mathrm{~m}, 5 \mathrm{H})$, $3.9-4.3(\mathrm{~m}, 1 \mathrm{H})$.

$\mathrm{N}, \mathrm{N}$-Dimethyl-4-methoxy-2-butynylamine (5f) was prepared according to Ref. 29.

General procedure for organocuprate reactions of acetylenic aminoethers. A Grignard reagent, derived from $\mathrm{Mg}(0.065 \mathrm{~mol})$ and an organic halide $(0.065 \mathrm{~mol})$ in an appropriate solvent, was cooled to $-30^{\circ} \mathrm{C}$. $\mathrm{CuI}$ or $\mathrm{CuBr}(0.0038-0.013 \mathrm{~mol})$ was then added over a 5-min period. A solution of an aminoether $5 a-g$ in THF or ether was then added dropwise in 5-min. Thereafter the reaction mixture was allowed to slowly reach room temperature. The mixture was quenched with water $(10 \mathrm{ml})$ when the reaction was complete $(2-21 \mathrm{~h})$, as determined by GLC. Diluted $\mathrm{NH}_{3}$ solution $(0.01 \mathrm{M}, 40 \mathrm{ml})$ was added to the mixture and it was extracted with ether $(3 \times 50 \mathrm{ml})$. The organic phase was washed with additional $\mathrm{NH}_{3}$ solution and water, dried over $\mathrm{Na}_{2} \mathrm{SO}_{4}-\mathrm{K}_{2} \mathrm{CO}_{3}$ and concentrated in vacuo. Distillation at reduced pressure gave the allenic amines $1 a-d, 7 a, b, f$ and $g$. They were characterized by NMR, IR and elemental analyses of their oxalates or hydrochlorides.

$\mathrm{N}-2,3$-Butadienyl- $\mathrm{N}$-methylbenzylamine (1a) ${ }^{4}$ Purified by preparative GLC. IR (film) $1955 \mathrm{~cm}^{-1}$. NMR $\left(\mathrm{CDCl}_{3}\right) 2.24(\mathrm{~s}, 3 \mathrm{H}), 3.0-3.2(\mathrm{~m}, 2 \mathrm{H}), 3.53$ $(\mathrm{s}, 2 \mathrm{H}), 4.8-4.55(\mathrm{~m}, 2 \mathrm{H}), 5.0-5.35(\mathrm{~m}, 1 \mathrm{H}), 7.32(\mathrm{~s}$, $5 \mathrm{H})$.

$\mathrm{N}-2,3-P e n t a d i e n y l-\mathrm{N}$-methylbenzylamine (1b). B.p. $94-96^{\circ} \mathrm{C} / 1.0 \mathrm{mmHg}$. IR (film) $1960 \mathrm{~cm}^{-1}$. $\left(\mathrm{CDCl}_{3}\right) 1.66$ (dd, 3H), 2.25 (s, 3H), $3.04(\mathrm{dd}, 2 \mathrm{H})$, $3.53(\mathrm{~s}, 2 \mathrm{H}), 4.95-5.3(\mathrm{~m}, 2 \mathrm{H}), 7.31(\mathrm{~s}, 5 \mathrm{H})$. The oxalate of $2 b$ had a m.p. of $135-136^{\circ} \mathrm{C}$ after recrystallization from ethanol-ether. Anal. $\mathrm{C}_{15} \mathrm{H}_{19} \mathrm{NO}_{4}: \mathrm{C}, \mathrm{H}, \mathrm{N}$.

$\mathrm{N}$-(4-Methyl-2,3-pentadienyl)-N-methylbenzylamine (1c). B.p. $78-79^{\circ} \mathrm{C} / 0.25 \mathrm{mmHg}$. IR (film) $1960 \mathrm{~cm}^{-1}$. NMR $\left(\mathrm{CDCl}_{3}\right) 1.69\left(\mathrm{~d},{ }^{5} J \sim 3 \mathrm{~Hz}, 6 \mathrm{H}\right)$, $2.24(\mathrm{~s}, 3 \mathrm{H}), 3.03\left(\mathrm{~d},{ }^{3} J \sim 7 \mathrm{~Hz}, 2 \mathrm{H}\right), 3.55(\mathrm{~s}, 2 \mathrm{H}), 4.5-$ $5.3(\mathrm{~m}, 1 \mathrm{H}), 7.32(\mathrm{~s}, 5 \mathrm{H})$. Oxalate of $2 c:$ m.p. $150-$ $151^{\circ} \mathrm{C}$ (recrystallized from ethanol-ether). Anal. $\mathrm{C}_{16} \mathrm{H}_{21} \mathrm{NO}_{4}: \mathrm{C}, \mathrm{H}, \mathrm{N}$. 
N,N-Dimethyl-2,3-heptadienylamine (1d). B.p. $98-101^{\circ} \mathrm{C} / 65 \mathrm{mmHg}$. IR (film) $1960 \mathrm{~cm}^{-1}$. NMR $\left(\mathrm{CDCl}_{3}\right) 0.95(\mathrm{t}, 3 \mathrm{H}), 1.2-2.2(\mathrm{~m}, 4 \mathrm{H}), 2.30(\mathrm{~s}, 6 \mathrm{H})$, 2.98 (dd, $2 \mathrm{H}) 4.9-5.25(\mathrm{~m}, 2 \mathrm{H})$. Oxalate of $2 d$ : m.p. $122-123^{\circ} \mathrm{C}$ (recrystallized from ethanol-ether). Anal. $\mathrm{C}_{11} \mathrm{H}_{19} \mathrm{NO}_{4}: \mathrm{C}, \mathrm{H}, \mathrm{N}$.

$\mathrm{N}$-(2-Methyl-2,3-butadienyl) - $\mathrm{N}$ - methylbenzylamine (7a). B.p. $64-65^{\circ} \mathrm{C} / 0.6 \mathrm{mmHg}$. IR (film) $1960 \mathrm{~cm}^{-1}$. NMR $\left(\mathrm{CDCl}_{3}\right) 1.64\left(\mathrm{t},{ }^{5} \sim 3 \mathrm{~Hz}, 3 \mathrm{H}\right)$, $2.16(\mathrm{~s}, 3 \mathrm{H}), 2.91\left(\mathrm{t},{ }^{5} \sim 2 \mathrm{~Hz}, 2 \mathrm{H}\right), 3.49(\mathrm{~s}, 2 \mathrm{H})$, $4.5-4.75(\mathrm{~m}, 2 \mathrm{H}), 7.30(\mathrm{~s}, 5 \mathrm{H}) .7 a$ was converted to a hydrochloride which, after recrystallization from ethyl acetate, had an m.p. of $119-121^{\circ} \mathrm{C}$. Anal. $\mathrm{C}_{13} \mathrm{H}_{18} \mathrm{ClN}$ : $\mathrm{C}, \mathrm{H}, \mathrm{N}$.

$\mathrm{N}-(2-$ Methyl-2,3-pentadienyl)- $\mathrm{N}$ - methylbenzylamine (7b). B.p. $76-77^{\circ} \mathrm{C} / 0.2 \mathrm{mmHg}$. IR (film) $1960 \mathrm{~cm}^{-1}$. NMR $\left(\mathrm{CDCl}_{3}\right), 1.61\left(\mathrm{~d},{ }^{3} \mathrm{~J} \sim 7 \mathrm{~Hz}, 3 \mathrm{H}\right)$, $1.73\left(\mathrm{~d},{ }^{5} \sim 3 \mathrm{~Hz}, 3 \mathrm{H}\right), 2.18$ (s, 3H), 2.90 (d, ${ }^{5} \sim 2 \mathrm{~Hz}$, $2 \mathrm{H}), 3.50(\mathrm{~s}, 2 \mathrm{H}), 4.8-5.2(\mathrm{~m}, 1 \mathrm{H}), 7.32(\mathrm{~s}, 5 \mathrm{H})$. Oxalate of $7 b$ : m.p. $124-125^{\circ} \mathrm{C}$ (recrystallized from ethanol-ether). Anal. Calc. for $\mathrm{C}_{16} \mathrm{H}_{21} \mathrm{NO}_{4}$ : C $66.0 ; \mathrm{H} 7.3 ; \mathrm{N} 4.8$. Found: C $65.4 ; \mathrm{H} 7.4 ; \mathrm{N} 4.8$.

$\mathrm{N}, \mathrm{N}$-Dimethyl-2-benzyl-2,3-butadienylamine (7f). B.p. $56-60^{\circ} \mathrm{C} / 0.15 \mathrm{mmHg}$. IR (film) $1960 \mathrm{~cm}^{-1}$. NMR $\left(\mathrm{CDCl}_{3}\right) 2.21(\mathrm{~s}, 6 \mathrm{H}), 2.76(\mathrm{t}, 2 \mathrm{H}), 3.36(\mathrm{t}, 3 \mathrm{H})$, $4.45-4.8(\mathrm{~m}, 2 \mathrm{H}), 7.28(\mathrm{~s}, 5 \mathrm{H})$. Hydrochloride of $7 f$ : m.p. $125-127^{\circ} \mathrm{C}$ (recrystallized from ethanolether). Anal. $\mathrm{C}_{13} \mathrm{H}_{18} \mathrm{ClN}$ : C,H,N.

2-Methyl-2,3-pentadienylamine (7g). B.p. 76$78^{\circ} \mathrm{C} / 100 \mathrm{mmHg}$. IR (film) $1960 \mathrm{~cm}^{-1}$. NMR $\left(\mathrm{CDCl}_{3}\right) 1.52(\mathrm{~s}, 2 \mathrm{H}), 1.62\left(\mathrm{~d},{ }^{3} \mathrm{~J} \sim 7 \mathrm{~Hz}, 3 \mathrm{H}\right), 1.66$ (d, $\left.{ }^{5} \mathrm{~J} \sim 4 \mathrm{~Hz}, 3 \mathrm{H}\right), 3.05\left(\mathrm{~d},{ }^{5} \mathrm{~J} \sim 3 \mathrm{~Hz}, 2 \mathrm{H}\right), 4.8-5.35$ (m, 1H). Hydrochloride of $7 g$ : m.p. $148-149^{\circ} \mathrm{C}$ (recrystallized from ethanol-ether). Anal. $\mathrm{C}_{6} \mathrm{H}_{12} \mathrm{ClN}$ : C,H,N.

Acknowledgement. Financial support, to A. Claesson, from IF:s stiftelse för farmaceutisk forskning, Apotekare C. D. Carlssons stiftelse, Lennanders fond, and $M$. Bergvalls stiftelse, is gratefully acknowledged,

\section{REFERENCES}

1. Singer, T. P., von Korf, R. W. and Murphy, D. L., Eds., Monoamine Oxidase: Structure, Function and Altered Functions, Academic, New York 1979.

2. Ho, B. T. J. Pharm. Sci. 61 (1972) 821.

3. Monoamine Oxidase and its Inhibition, Ciba Foundation Symposium 39, Elsevier, Amsterdam 1976.

4. Halliday, R. P., Davis, C. S., Heotis, J. P., Pals, D. T., Watson, E. J. and Bickerton, R. K. J. Pharm. Sci. 57 (1968) 430.

5. Krantz, A. and Lipkowitz, G. S. J. Am. Chem. Soc. 99 (1977) 4156.
6. Maycock, A. L., Abeles, R. H., Salach, J. I. and Singer, T. P. Biochemistry 15 (1976) 114.

7. The biochemical data and the preparation of labeled allenic amines will be reported elsewhere. For a preliminary report see; Krantz, A., Kokel, B., Sachdeva, Y. P., Salach, J., Claesson, A. and Sahlberg, C. In Kalman, T. Ed., Drug Action and Design: Mechanism-based Enzyme Inhibitors, Elsevier/North-Holland 1979, p. 145.

8. a. Carothers, W. H. and Berchet, G. J. U.S. Pat. 2136 177; Chem. Abstr. 33 (1939) 1344; b. Engelhardt, V. A. J. Am. Chem. Soc. 78 (1956) 107.

9. a. Mauze, B. J. Organometal. Chem. 134 (1977) 1; b. Bertrand, M., Gras, J.-L. and Galledou, B. S. Tetrahedron Lett. (1978) 2873; c. Santelli, C. Tetrahedron Lett. (1980) 2893.

10. Claesson, A. and Sahlberg, C. Tetrahedron. In press.

11. For a preliminary account of this work see; Claesson, A. and Sahlberg, C. Tetrahedron Lett. (1978) 1319.

12. a. Crabbé, P. and Carpio, H. Chem. Commun. (1972) 904; b. Luché, J. L., Barreiro, E., Dollat, J. M. and Crabbé, P. Tetrahedron Lett. (1975) 4615; c. Crabbé, P., Barreiro, E., Dollat, J. M. and Luché, J. L. Chem. Commun. (1976) 183.

13. a. Vermeer, P., Meijer, J. and Brandsma, L. Recl. Trav. Chim. Pays-Bas 94 (1975) 112; b. Pasto, D. J., Chou, S. K., Fritzen, E., Schults, R. H., Waterhouse, A. and Hennion, G. F. J. Org. Chem. 43 (1978) 1389; c. Ortiz de Montellano, P. Chem. Commun. (1973) 709; d. Claesson, A., Tämnefors, I. and Olsson, L.-I. Tetrahedron Lett. (1975) 1509.

14. Baret, P., Barreiro, E., Greene, A. E., Luché, J. L., Teixeira, M.-A. and Crabbé, P. Tetrahedron 35 (1979) 2931.

15. Claesson, A. and Sahlberg, C. J. Organomet. Chem. 170 (1979) 355.

16. Claesson, A., Åsell, A., Björkman, S. and Olsson, L.-I. Acta Pharm. Suec. 15 (1978) 105.

17. Sahlberg, C. and Claesson, A. Unpublished results.

18. Olsson, L.-I. and Claesson, A. Acta Chem. Scand. B 33 (1979) 679.

19. Moreau, J. L. and Gaudemar, M. J. Organomet. Chem. 108 (1976) 159.

20. Posner, G. H. An Introduction to Synthesis Using Organocopper Reagents, Wiley-Interscience, New York 1980, p. 7.

21. Smith, R. A. J. and Hannah, D. J. Tetrahedron 35 (1979) 1183.

22. Kirksey, S. T., Jr., Neubecker, T. A. and Margerum, D. W. J. Am. Chem. Soc. 101 (1979) 1631 and references therein.

23. Mkryan, G. M., Gasparayan, S. M. and Mekongan, N. K. Zh. Org. Khim. 7 (1971) 27. 
24. Normant, J. F., Alexakis, A. and Villieras, J. J. Organomet. Chem. 57 (1973) C99.

25. Normant, J. F. In Seyferth, D., Ed., New Applications of Organometallic Reagents in Organic Synthesis, Elsevier, Amsterdam 1976, p. 225.

26. Brandsma, L. Preparative Acetylenic Chemistry, Elsevier, Amsterdam 1971.

27. Kirmse, W., Engelmann, A. and Heese, J. Chem. Ber. 106 (1973) 3073.

28. Kreevoy, M. M., Charman, H. B. and Vinard, D. R. J. Am. Chem. Soc. 83 (1961) 1978.

29. Guermont, J. P. Bull. Soc. Chim. Fr. (1953) 386.

Received November 4, 1981. 